\title{
Pine Tar and the Infield Fly Rule: An Umpire's Perspective on the Hart-Dworkin Jurisprudential Debate
}

\author{
William D. Blake, Ph.D. ${ }^{1}$ \\ Assistant Professor \\ Department of Political Science \\ Indiana University, Indianapolis (IUPUI) \\ wblake04@gmail.com
}

\begin{abstract}
What is law? Though on its face this question seems simple, it remains an incredibly controversial one to legal theorists. One prominent jurisprudential debate of late occurred between H.L.A. Hart, a positivist, and Ronald Dworkin, an interpretivist. While positivism, at its core, holds the law is a set of authoritative commands, Dworkin rejects this reflexive approach and instructs judges to incorporate and advance communal norms and morals in their decisions. In baseball, umpires utilize both legal theories, depending on the type of rule they are asked to interpret or enforce. I conclude that, like umpires, most citizens are not dogmatic about either legal theory.
\end{abstract}

\footnotetext{
${ }^{1}$ I wish to thank Justice George Nicholson of the California Court of Appeal for encouraging my participation at this Symposium. I am eternally grateful to former Major Leaguer Jim Abbott for taking the time to respond to my questions. Finally, to the 13 year-old pitcher whom I discuss in this paper: your courage and enthusiasm are inspiring, but, for Pete's sake, please practice coming set.
} 
Bill Klem, one of the ${ }^{2}$ first umpires inducted into the Baseball Hall of Fame, once wrongly called a runner out at home plate. A lucky newspaper photographer snapped a shot, which demonstrated Klem's mistake. The next day, reporters demanded to know how the batter could be out in light of the incontrovertible photographic evidence. "Gentlemen," quipped Klem, "he was out because I said he was out."3 Though this retort seems trivial, it provides useful insight into the relationship between rules and authority in baseball. The baseball rulebook invests the umpire as "the representative of the league and of professional baseball" and authorizes him (or her ${ }^{4}$ ) to enforce every rule. The commissioner, baseball's unquestioned sovereign, ${ }^{5}$ deputizes umpires with much of his own authority and discretion.

The phrase "in the umpire's judgment," or a phrase to that effect, occurs 79 times throughout the rulebook. A judgment call by an umpire cannot be appealed ${ }^{6}$ nor become grounds for protest, ${ }^{7}$ regardless of how badly blown the call appears to be. The rulebook even anticipates its own incompleteness and authorizes umpires to use their judgment to resolve any situation "not specifically covered."8 Political commentator George Will summarized the nature of an umpire's authority by stating: "If the Constitution is what the Supreme Court says it is, then the strike zone is what umpires say it is." 9

What should an umpire say the strike zone is? In other words, how do umpires identify, interpret, and apply the laws of baseball? I have previously contended that umpiring provides

\footnotetext{
${ }^{2}$ Aside, "Common Law Origins of the Infield Fly Rule," University of Pennsylvania Law Review 123, no. 6 (1975): n. 1 .

3 "Bill Klem Quotes," Baseball Almanac, 2012, http://www.baseball-almanac.com/quotes/quoklem.shtml.

${ }^{4}$ Bruce Weber, As They See "Em: A Fan"s Travels in the Land of Umpires (New York: Scribner, 2009), 148.

${ }^{5}$ David Pietrusza, Judge and Jury: The Life and Times of Judge Kenesaw Mountain Landis (New York: Taylor Trade Publishing, 1998).

${ }^{6}$ Playing Rules Committee, Official Baseball Rules (New York: Commssioner of Baseball, 2013), Rule 9.02(c), http://mlb.mlb.com/mlb/downloads/y2013/official_baseball_rules.pdf.

${ }^{7}$ Ibid., Rule 4.19.

${ }^{8}$ Ibid., Rule 9.01(c).

${ }^{9}$ Quoted in Weber, As They See 'Em, 167.
} 
insight into the jurisprudential debate over legal formalism and realism. ${ }^{10}$ Here, I take the umpires-as-judges analogy further to consider another important debate in jurisprudence between H.L.A. Hart ${ }^{11}$ and Ronald Dworkin. ${ }^{12}$ Hart was, perhaps, the greatest $20^{\text {th }}$ century advocate of legal positivism, which holds that "law is a matter of what has been posited (ordered, decided, practiced, tolerated, etc.)." ${ }^{\prime 3}$ To a positivist, it is not the role of a judge to question whether the rules promote morality or utility; the judge must only see that they are enforced. Dworkin countered many of Hart's arguments in his interpretivist theory of law, which holds "that legal rights and duties are determined by the scheme of principle that provides the best justification of certain political practices of a community." $" 14$ To Dworkin, when specific rules undermine broader principles, the latter ought to prevail in judicial decisions.

The umpires-as-judges analogy can provide a lens through which to understand the differences between these theories of jurisprudence, which might be an easier way to introduce these concepts to undergraduate students. No analogy can fully explain how one institution works because analogies, by definition, invite comparisons to institutions that are different. However, analogies are a useful way of breaking down a complex topic, like judging, in terms of a more easily understood topic, such as umpiring. As I intend to demonstrate, neither legal theory holds a monopoly in the practice of umpiring, and — from my standpoint as an umpirethis makes the game better. Likewise, neither jurisprudence holds a monopoly in the

\footnotetext{
10 “Umpires as Legal Realists,” PS: Political Science \& Politics 45, no. 2 (2012): 271-76.

${ }^{11}$ H. L. A Hart, "Positivism and the Separation of Law and Morals," Harvard Law Review 71 (1957): 593; H. L. A. Hart, The Concept of Law (New York: Oxford University Press, USA, 1961).

${ }^{12}$ Ronald Dworkin, Taking Rights Seriously (Cambridge, MA: Harvard University Press, 1978); Ronald Dworkin, Law's Empire (Cambridge, MA: Harvard University Press, 1986).

${ }^{13}$ Leslie Green, "Legal Positivism," in The Stanford Encyclopedia of Philosophy, ed. Edward N. Zalta, 2009, http://plato.stanford.edu/archives/fall2009/entries/legal-positivism/.

${ }^{14}$ Nicos Stavropoulos, "Interpretivist Theories of Law," in The Stanford Encyclopedia of Philosophy, ed. Edward N. Zalta, Fall 2008, 2008, http://plato.stanford.edu/archives/fall2008/entries/law-interpretivist/.
} 
interpretation of law because a slavish adherence to a single philosophy could lead to perverse results in many cases.

\section{The Infield Fly Rule: Purposeful Origin, Positivist Enforcement}

The 2012 Major League Baseball playoffs were memorable for a number of reasons, ${ }^{15}$ one of which was the creation of a win-or-go-home Wild Card game in both leagues. In the National League contest, the St. Louis Cardinals beat the Atlanta Braves in a game filled with controversy. In the bottom of the $8^{\text {th }}$ inning, the Braves trailed 6-3, but were threatening with runners on first and second and one out. Braves shortstop Andrelton Simmons hit a high fly ball that slowly drifted over the infield and into left field. As leftfielder Matt Holliday moved in to back up the play, shortstop Pete Kozma tracked the ball and camped under it to make the catch. Leftfield umpire ${ }^{16}$ Sam Holbrook then indicated, both verbally and mechanically, the infield fly rule was in effect. At the last minute, Kozma lost his concentration and the ball fell to the ground, but Simmons, of course, was still out. The runners on first and second advanced one base each at their own peril.

Braves fans, players, and manager Fredi Gonzalez were stunned, but there is a good case to be made that this was the correct call. The infield fly rule should only be invoked if a fly ball is hit that can be caught by an infielder with ordinary effort. ${ }^{17}$ Ordinary effort is defined as "the effort that a fielder of average skill at a position in that league or classification of leagues should

\footnotetext{
${ }^{15}$ The lasting contribution to baseball history, of course, was the return of the Washington Nationals to the playoffs after a 79-year hiatus. Mark Patrick, "Drew Storen's Father on the Agonizing and Amazing Feeling of Watching His Son," Sports Illustrated, September 27, 2012, http://sportsillustrated.cnn.com/2012/baseball/mlb/09/27/drew-storenmark-patrick-nationals/index.html?mobile=no.

${ }^{16}$ Major League Baseball adds two additional umpires to the typical four-man crew for all playoff games and the All-Star Game, one stationed along each outfield line. "Umpires: Timeline," Major League Baseball, accessed July 1, 2013, http://mlb.mlb.com/mlb/official_info/umpires/timeline.jsp.

${ }^{17}$ The rule only applied in situations (like this one) with runners on first and second or bases loaded and less than two outs. Playing Rules Committee, Official Baseball Rules, Rule 2.00 Infield Fly.
} 
exhibit on a play, with due consideration given to the condition of the field and weather conditions." 18 The rulebook also instructs umpires not to consider "some arbitrary limitation such as the [outfield] grass" to determine where ordinary effort ends. ${ }^{19}$ That is, regardless of how the play turned out in that particular instance, the question for the umpire is: would the typical Major League shortstop be able to make that play under similar circumstances? In Holbrook's opinion, the answer was yes. ${ }^{20}$

From the intricate test used to apply the Infield Fly Rule, casual baseball fans may not understand what good the rule accomplishes. The underlying principle justifying the rule is that a player should not benefit from his own unethical conduct. ${ }^{21}$ Imagine what would happen without this rule. The bases are loaded with one out. The batter hits a routine fly ball to the third baseman in fair territory. The runners have an incentive to stay close to their bases because they do not want to be forced out trying to advance if the catch is made. However, the third baseman observes that a double play can get their team out of the jam. Knowing the runners are close to their bases, he allows the ball to drop, picks it up, steps on third base for one force out and fires it onto second for the final out of the inning.

An early version of Infield Fly Rule was added to the rulebook sometime in the mid$1890 \mathrm{~s}^{22}$ after players began to exploit the incompleteness of the rules at the time. For example, in an 1893 game between the Baltimore Orioles and New York Giants, a fast Oriole runner was

\footnotetext{
${ }^{18}$ Ibid., Rule 2.00 Ordinary Effort.

${ }^{19}$ Ibid., Rule 2.00 Infield Fly, Comment.

${ }^{20}$ I personally agree with Holbrook's call both at the time and in retrospect. Advanced defense metrics do not rate Kozma very highly, so it is quite plausible a better shortstop would have made that play look more routine. "Pete Kozma," Baseball-Reference.com, accessed May 29, 2013, http://www.baseballreference.com/players/k/kozmape01.shtml.

${ }^{21}$ Dworkin, Law's Empire, 17-20; Riggs v. Palmer, 115 N.Y. 506 (New York Court of Appeal 1889).

${ }^{22}$ Aside, "Common Law Origins of the Infield Fly Rule," n. 5.
} 
at first with only one out. A batter with the "speed of an ice wagon",23 then hit a routine pop-up to Giants shortstop, and future attorney and players' union activist, John Montgomery Ward. ${ }^{24}$ The runner on first stayed on the base, but Ward let the ball drop and then threw to second to get the speedy runner out. While this incident did not result in a double play, it established a precedent for New York chicanery against Baltimore, which has only grown over the following century. $^{25}$

Returning to the Wild Card game, Holbrook waited to make the call until Kozma camped under the ball because it was at that point he was satisfied the play involved ordinary effort. Holbrook exercised only a small bit of discretion by waiting until he was sure the call was appropriate. Braves fans had wished him exercise more discretion by not making the call at all, as there was no way that St. Louis could turn this situation into a double place. In the umpire's mind, however, it did not matter that the ball was deep enough in the outfield that no chicanery would have led to a double play. The play met the test; the rule was applied. Judicial application of the law without questioning the underlying relevance of the law is a crucial argument in legal positivism. As the English judge John Austin put it: "The existence of law is one thing; its merit and demerit another." 26 A judge's job, in the positivist mold, is to deal with

\footnotetext{
${ }^{23}$ Ibid., 1477. While the absolute speed of an ice wagon remains a mystery of modern physics, new legal research sheds light on the relative speed of an ice wagon. Ibid., n. 26. In South Covington \& Cincinnati St. Ry. Co. v.Crutcher, 135 Ky. 698 (Kentucky Court of Appeals 1909). the Kentucky Court of Appeals found that an ice wagon moves slowly enough to allow a 69-year-old woman to move from one side of a street car to the other, hoping to protect herself, just as an accident with an ice wagon was about occur. The driver of the street car believed the ice wagon to be traveling very quickly, testifying: "The wagon was coming like the fire department" (702). However, his perception deceived him because when he slowed the street car down in an attempt to let the ice wagon cross the intersection first, he ultimately brought about the collision.

${ }^{24}$ David Stevens, Baseball's Radical for All Seasons: A Biography of John Montgomery Ward (Scarecrow Press, 1998).

${ }^{25}$ Dan Connolly, "Sixteen Years Later, Jeffrey Maier Revisits Infamous Moment in Yankee Stadium," Baltimore Sun, October 12, 2012, http://articles.baltimoresun.com/2012-10-09/sports/bs-sp-orioles-yankees-maier-101020121009_1_jeffrey-maier-infamous-moment-orioles.

${ }^{26}$ The Province of Jurisprudence Determined (Cambridge, UK: Cambridge University Press, 1995), 157.
} 
the first problem only. Thus Holbrook's interpretive question involved only facts, not any deeper issue of morality.

\section{Pine Tar Positivism}

One of the most bizarre baseball incidents of all time took place in 1983 in a game between the Kansas City Royals and the New York Yankees. In the top of the ninth inning, Royal great George Brett hit a home run to give Kansas City the lead. Yankee manager Billy Martin approached home plate umpire Tim McClelland, who was in his first year at the major league level, to argue that Brett's bat had too much pine tar on it. ${ }^{27}$ Rule $1.10(\mathrm{c})$ states that a batter may not apply pine tar more than 18 inches beyond the handle of the bat. ${ }^{28}$ At the time, Rule $6.06(a)^{29}$ read that a player is out when "[h]e hits an illegally batted ball." ${ }^{, 30}$ McClelland measured the bat, found pine tar beyond the rulebook limit, and called Brett out, nixing the home run. McClelland defended his decision, saying: "We had done what we do-administer the rules." 31 He added, "I can't rule on the spirit of a rule."32

The Yankees won the game, but the Royals protested the game to league officials. According to my reading of the rulebook, this protest should have been denied purely on jurisdictional grounds. Rule 4.19 states: "Each league shall adopt rules governing procedure for protesting a game, when a manager claims that an umpire's decision is in violation of these

\footnotetext{
${ }^{27}$ You can come to your own conclusion by viewing the bat at the National Baseball Hall of Fame. Tyler Kepner, "Whatever Happened to Brett's Pine-Tar Bat?," The New York Times Baseball Blog, July 24, 2008, http://bats.blogs.nytimes.com/2008/07/24/what-ever-happened-to-bretts-pine-tar-bat/.

${ }^{28}$ Playing Rules Committee, Official Baseball Rules.

${ }^{29}$ Rule 6.06(a) has since been eliminated from the rulebook. Jared Tobin Finkelstein, "In Re Brett: The Sticky Problems of Statutory Construction," Fordham Law Review 52 (1984 1983): 430.

${ }^{30}$ Quoted in ibid., 432.

${ }^{31}$ Quoted in Mark Lelinwalla, “George Brett and Umpire Recall Yankee Stadium Pine Tar Game,” New York Daily News, July 23, 2008, http://www.nydailynews.com/sports/baseball/yankees/2008/07/23/2008-07-

23_george_brett_and_umpire_recall_yankee_st.html.

32 Quoted in Bruce Weber, "Umpires V. Judges," The New York Times, July 12, 2009, sec. Week in Review, 317, http://www.nytimes.com/2009/07/12/weekinreview/12weber.html?hp.
} 
rules" (emphasis added). ${ }^{33}$ The pine tar rules on the book at the time might have been

nonsensical, but they were rules nonetheless. From a positivist standpoint, McClelland identified the relevant law and applied the remedy authorized by it when a violation occurred.

American League President Lee MacPhail saw it differently. He not only agreed to hear the protest, he upheld it on the grounds that Brett's violation of the pine tar rule did not constitute unfair play. MacPhail allowed the home run to stand and ordered the two teams to replay the rest of the game, starting after Brett's home run in the top of the ninth inning, later that season. This time around, the Royals held on to win. The topic remains a sore one for Brett to this day. ${ }^{34}$

\section{A Balk in the Park}

Major League umpires are not the only ones who occasionally find themselves under fire for their positivist approach to the game. I umpired on behalf of the Northern Virginia Baseball Umpires Association in the fall of 2012. The game involved two teams of 13-year olds. During the pre-game conference, I asked both coaches whether there were any local rules or customs that I needed to be aware of to call the type of game they expected. In particular, in some less competitive leagues balks would be called, but not enforced—-the runners would not advance as a penalty. Both coaches insisted that their league had called and enforced the balk rule the whole season.

One team had a player whom I suspect has a form of cerebral palsy. While he did not get much function out of his right side, he batted left-handed and played in the infield and outfield early in the game. When catching and throwing, he would catch the ball with a glove on his left hand and then transfer the glove to his right side to free up his left arm for throwing, a method

\footnotetext{
${ }^{33}$ Playing Rules Committee, Official Baseball Rules.

${ }^{34}$ For another infamous instance of George Brett experiencing soreness, see Associated Press, "Brett in Hospital for Surgery," The New York Times, March 1, 1981, sec. Sports, http://www.nytimes.com/1981/03/01/sports/brett-inhospital-for-surgery.html..
} 
similar to that used by former Major League pitcher Jim Abbott. ${ }^{35}$ Later in the game, the teenage version of Jim Abbott came into pitch with runners on base. I was working behind the plate, I could tell from his warm-up pitches he was excited to be given the chance to pitch. He was working very quickly to deliver each pitch.

When the game resumed, the new pitcher really was not allowing much time, if any, to pause after transferring the glove from his left hand to his right hand before making his next pitch. Rule 8.01(b) lays out one part of the infamous balk rule:

The pitcher, following his stretch, must (a) hold the ball in both hands in front of his body and (b) come to a complete stop. This must be enforced. Umpires should watch this closely. Pitchers are constantly attempting to "beat the rule" in their efforts to hold runners on bases and in cases where the pitcher fails to make a complete "stop" called for in the rules, the umpire should immediately call a "Balk.",

In baseball vernacular, this is the requirement for pitchers to "come set," that is, to reach the Set Position, one of the only two legal pitching positions. Coming set is important because the failure to do so would often disadvantage the timing of the runners on base. While the rulebook defines a balk using a triskaideca-partite test, ${ }^{37}$ the essence of the rule is to identify and punish behavior on the part of the pitcher intended to deceive the runner. ${ }^{38}$

When calling 13-year old games, umpires are encouraged not to be too officious in finding every possible balk violation, so I did not call a several, slight violations. On one pitch, however, this pitcher committed the worst violation of that part of the balk rule I had ever seen. I called the balk and advanced the runners. I called time so I could go out and talk to the pitcher about what had happened and how he could improve. I took three steps towards the mound

\footnotetext{
${ }^{35}$ Abbott, incidentally, is also left-handed. Jim Abbott and Tim Brown, Imperfect: An Improbable Life (Ballantine Books, 2013).

${ }^{36}$ Playing Rules Committee, Official Baseball Rules.

${ }^{37}$ Perhaps the next time a Supreme Court justice complains about the tri-partite Lemon test being unenforceable, they should consider how much worse it would be if it had 13 component parts like the balk rule. 403 U.S. 602 (1971).

${ }^{38}$ Interestingly, despite the fact that umpires will universally use the term "to deceive the runner" colloquially to identify the conduct subject to the balk rule, that term appear s once in the rulebook as fairly minor comment

Official Baseball Rules, Rule 8.05 Comment (a).
} 
when he said to me, "I didn't come set, did I?" I told him that he had not, and I gave him some suggestions on how to work a bit slower. By the end of the inning, he was following the rule perfectly to the letter.

From my vantage point, I did not think that the pitcher intended to deceive the runner, even though he engaged in conduct which is falls under the prevue balk rule. Thus, my call was most certainly a positivist one. Even at the big league level, many balk calls were not the result of a deliberate attempt to catch a runner off guard. For example, earlier this year Nationals pitcher Gio Gonzalez faced a bases-loaded situation. Because the threat of a stolen base was minimal, Gio switched his pitching position from stretch back to the windup, which is typically employed only the bases are empty. He and catcher Kurt Suzuki could not agree on a pitch to throw, so he stepped off the mound with his right foot. As a left-handed pitcher, this is a balk, ${ }^{39}$ and home plate umpire Phil Cuzzi made the call. ${ }^{40}$ Everyone on the field, including Cuzzi, understood that the play was nothing more than a mental mistake, especially since the only base that could be stolen was home. The lack of intent to deceive the runner, however, did not influence the umpire's application of the rules.

\section{Baseball as a Social Practice}

As it turns out, the teenage Jim Abbott was probably the only person at that stadium who understood what I did and why. The coaches of both teams criticized me, as did my umpiring partner. I did not have any qualms about my action, but in that moment, I suddenly realized that my interpretation of the balk rule did not fit within that particular baseball community. All the other players, coaches, and parents, shared a set of norms that deviated significantly from the text

\footnotetext{
${ }^{39}$ Ibid., 8.01(a) (comment).

${ }^{40}$ Dan Kolko, "Gonzalez Battling Himself This Time Out (Nats Take the Lead)," Nationals Pastime, April 9, 2013, http://www.masnsports.com/nationals_pastime/2013/04/gonzalez-battling-himself-this-time-out.html.
} 
in the rulebook; none of them would have called the balk. That deviation from legal text, according to a positivist, is dangerous because it undermines the rule of law to favor mob rule. To a positivist, if the rule is unfair, the Commissioner must change it authoritatively, as opposed to an ad hoc change by an umpire.

By contrast, Dworkin conceives of judges as interpreters because all social practices, including law, have meaning because they are more than just accidents of history; they exist in support of a social value or principle. All forms of interpretation, whether artistic, scientific, or legal, must attempt to understand the purpose of the practice being interpreted. One social practice Dworkin analyses is removing one's hat in the presence of superiors. Interpreting the purpose of this social practice breathes life into a potentially mechanical and empty gesture of courtesy.

Dworkin acknowledges two forms of skepticism about interpreting social practices: an internal form and an external one. The internal version of skepticism involves arguments over different ways to construct the best interpretation of a social practice. An internal skeptic would ask: are there other, better purposes served by the practice of removing one's hat besides courtesy? The external skeptic, on the other hand, does not think that something like courtesy exists in a meaningful way. When I inquired about any special rules during my pre-game conference with the coaches, I was attempting to approach the practice of baseball from the perspective of an internal skeptic. In other words, I was attempting to understand how best to connect my interpretation of the balk rule to fit the goals pursued by these teams in this league. That attempt failed spectacularly. Instead, the parents and coaches perceived me as an external skeptic — someone totally unconcerned with larger issues of fairness, which is probably why they were upset with me. 
A Dworkinian judge probably would have said that not calling a balk in this instance is not a deviation from the rule; he would call that consensus shared by everyone (except me) the real rule. Interpretivism holds that judicial opinions tell a story about underlying community values. Thus, the key for judges is asking "[w]hich story shows the community in a better light, all things considered, from the standpoint of political morality?" ${ }^{41}$ Dworkin, had he been alive and present at that field in Northern Virginia, would have likely told me that the constructive interpretation of the baseball rulebook, for the purposes of a 13-year old game, would require me not to call the balk. Dworkin believes positivists are external skeptics in this way.

A Dworkinian judge would have likely identified two principles involved in that aspect of the social practice of baseball. On the one hand, the value of sportsmanship involves acting generously towards all fellow players. On the other hand, baseball is a democratic game in the sense that its rules are (or, at least, are supposed to $\mathrm{be}^{42}$ ) applied evenly. ${ }^{43}$ That judge would then prioritize the principle of sportsmanship. One of Dworkin's key concerns is that "individuals have a right to equal concern and respect" from their government. ${ }^{44}$ In particular, the judge might have cited Rule 8.02(a)(1) which allows pitchers to blow on their hand in cold weather, despite the risk that such behavior could result in throwing a spitball. ${ }^{45}$ Such an accommodation in the rulebook promotes a Dworkinian idea of justice as fairness.

Interestingly, Jim Abbott (the former big leaguer, that is) disagrees! I contacted Abbott through his publicist in the hopes of gaining his perspective on the situation in part because

\footnotetext{
${ }^{41}$ Dworkin, Law's Empire, 249.

${ }^{4242}$ Hitters with excellent batting eyes often time receive deference from umpires on borderline calls (and vice versa for very precise pitchers). A rookie pitcher once nervously faced Hall of Famer Rogers Hornsby. He tried painting the corners, but umpire Bill Klem called the first three pitches balls. The pitcher complained, "Umpire, those were strikes!" Klem retorted: "Son, when you pitch a strike, Mr. Hornsby will let you know." Geoffrey C. Ward, Baseball: An Illustrated History (Random House Digital, Inc., 1996), 173.

${ }^{43}$ See Herbert Wechsler, "Toward Neutral Principles of Constitutional Law," Harvard Law Review 73, no. 1 (1959): 32.

${ }^{44}$ Dworkin, Taking Rights Seriously, 82.

${ }^{45}$ Playing Rules Committee, Official Baseball Rules.
} 
Abbott faced similar physical limitations and committed nine balks in his first three big league seasons. ${ }^{46}$ His reply to me reads in part: "The situation you bring up is a tricky one and I could see the argument for both sides. To be honest I never sought any exemption from the rules of the game, in fact the opposite was true, I wanted to be judged in the same exact way the other players on the field were judged. I would be willing to bet the young man you mentioned probably feels the same way."47

\section{“For It's One, Two, Three Strikes, You're Out”: Dworkin's Misunderstanding of Baseball}

To contrast interpretivism from positivism, Dworkin employs a baseball analogy in developing his argument about different types of discretion that officials, including judges, are thought to have. He sets up three different types of discretion: two weak and one strong form. The first weak form of discretion is "for some reason the standards an official must apply cannot be applied mechanically but demand the use of judgment." ${ }^{, 4}$ By the word "judgment," Dworkin means expert evaluation and assessment. Certainly, successful umpires exercise this kind discretion by making snap judgments (safe/out, fair/foul, strike/ball, etc.) much more accurately than fans or even players.

Dworkin's second weak sense of discretion outlines the finality of authority: “[T]he decision whether the ball or the runner reaches second base first...[is] left to the discretion of the second base umpire if we mean that on this issue the head umpire has no power to substitute his own judgment if he disagrees." This analogy also works well. If the second base umpire makes

\footnotetext{
46 “Jim Abbott,” Baseball-Reference.com, accessed May 20, 2013, http://www.baseballreference.com/players/a/abbotji01.shtml. Regarding his own pitching mechanics, Abbott told me: "The American League umpires initially looked at the way I twirled the ball in the set position, in order to decide if this was actually considered a full stop in the stretch. After looking it over they decided that it was allowable. After that initial ruling I never recall that issue being brought up.” Abbott, Jim, e-mail to William Blake, 20 May 2013.

${ }^{47}$ Abbott, e-mail.

${ }^{48}$ Taking Rights Seriously, 31.
} 
a terrible call in the situation Dworkin mentions, the opposing team manager might come out and argue the call, but the manager has no right to appeal the call to another umpire in the hopes that the other umpire saw a different situation.

The strong sense of discretion according to Dworkin occurs when judges find themselves not bound by an external authority, only to his own sense of fairness. Positivists, according to Dworkin, do not recognize the potential for this strong sense of discretion for judges. The problem with this approach, according to Dworkin, is that the legal system in a positivist world is merely a collection of rules. Dworkin views the legal system as something more. Judges must strive to understand and uphold the principles of a particular legal system, even if they are not perfectly expressed in a given set of rules.

Dworkin's distinction between rules and principles rests in large part on the universal applicability of rules, whereas principles are weighed against other principles. As a demonstration, Dworkin turns to baseball, a game, which he claims, is dominated by rules, rather than principles. He writes, "In baseball a rule provides that if the batter has had three strikes, he is out." ${ }^{49}$ He goes on:

In other systems of rules with which [a judge] has experience (like games), the rules are the only special authority that govern official decisions, so that if an umpire could change a rule, he would have discretion as to the subject of that rule. Any principles umpires might mention when changing the rules would represent only their 'characteristic' preferences. Positivists treat law like baseball revisited in this way. ${ }^{50}$

Dworkin thinks umpires are positivists and would adopt the positivist perspective on rule deviation. Because positivists are concerned with rules and not principles, when umpires change the rules, they do so in a way that simply a reflection their predilections, or perhaps their choice of pre-game meal. ${ }^{51}$ In other words, there is no deeper interpretive or philosophical dimension to

\footnotetext{
${ }^{49}$ Ibid., 24.

${ }^{50}$ Ibid., 39.

51 “[A] judicial decision might be determined by what the judge had for breakfast." Jerome Frank, Courts on Trial
} 
this decision. I doubt the "framers" of the rulebook share that sentiment as they explicitly give umpires the authority to rule on "any point not specifically covered" by the rules. ${ }^{52}$

Dworkin's understanding of baseball and discretion is also inconsistent with his larger argument for constructive interpretation because what appears to Dworkin as a series of simple commands in the baseball rulebook also contain important principles that define the national pastime. In the case of baseball, an umpire must decide what weight to assign to the rule of the strike zone, an application of which might weaken larger principles of baseball, such as sportsmanship or player safety. Professor Mark Graber, the true founder of the law and sports officiating movement, ${ }^{53}$ has pointed out that sports officials often stretch or ignore otherwise clear rules, such as when umpires in a recreational softball league adopt a wide strike zone to encourage players to swing more frequently. ${ }^{54}$

Umpires also have the authority to eject players for "unsportsmanlike conduct," "55 a rule that invites interpretation based on the principles of sportsmanship. Another principle embedded within the social practice of baseball is player safety. For instance, consider the "neighborhood play." When a double play is being turned, often the second baseman (or shortstop) will be near second base, without actually touching it, before throwing on to first base to complete the double play. The umpire will still call the runner out at second base, even though this action does not

(Princeton: Princeton University Press, 1973), 208.

${ }^{52}$ Playing Rules Committee, Official Baseball Rules, Rule 9.01(c).

${ }^{53}$ Mark A Graber, "Law and Sports Officiating: A Misunderstood and Justly Neglected Relationship," Constitutional Commentary 16 (1999): 293-314.

${ }^{54}$ Major League Baseball has recently attempted to reign in the degree of discretion umpires exercise when calling balls and strikes by implementing a computerized analysis of balls and strikes in 2003. The top of the strike zone should be around the bottom of the batters rib cage. Playing Rules Committee, Official Baseball Rules, Rule 2.00 Strike Zone..Even the most casual of baseball fans will observe that umpires almost never call strikes that high and have not done so since the 1960s. Douglas O. Linder, "Strict Constructionism and the Strike Zone," UMKC Law Review 56, no. 1 (1987): 117-20. An operator of the QuesTec computer system indicated in 2004 that the program measures the top of the strike zone at the "top of the belt," which is still a good two balls smaller than the rulebook strike zone. Jason Karegeannes, "Confessions of a Questec Operator,” Baseball Prospectus, August 10, 2004, http://www.baseballprospectus.com/article.php?articleid=3326.

55 Playing Rules Committee, Official Baseball Rules, 9.01(d). 
meet the rulebook definition of a force out. ${ }^{56}$ Umpires utilize this discretion to protect the middle infielders from suffering a perfectly legal collision from a runner sliding hard into second base. As Major League umpire Tom Hallion said in an interview: "You would give him the call even if he's not right on the bag ... [b]ecause if I call the guy safe, here's what [the defensive team's coaches] say: 'Do you want this guy [expletive] killed?',57

Despite the fact that the neighborhood play operates contrary to the rules of baseball, players and managers expect this principle to trump the rule. In the 2009 American League Championship Series, second base umpire Jerry Layne refused to give Angels shortstop Erick Aybar credit for recording an out at second while attempting to turn a double play. Usually managers will argue with umpires when they miss an opportunity to enforce a rule that would work to the advantage of their team. In this case, Angels manager Mike Scoscia angrily confronted Layne for missing an opportunity to ignore a rule that would have helped the Angels. $^{58}$

Thus, while Dworkin's approach to interpretivist offers a fair amount of purchase into the approach that umpires adopt in many situations, Dworkin's attempt to analogize umpiring to judging largely failed. Dworkin's misunderstanding of umpiring might be a result of the speed at which the game is played. When deciding whether to call a ball or strike, umpires usually ${ }^{59}$ render a verdict within a second of the ball hitting the catcher's mitt. Dworkin wants a judge to

\footnotetext{
56 "Any runner is out when...[h]e or the next base is tagged before he touches the next base." Ibid., 7.08(e). The folklore notwithstanding, in baseball the tie does not go to the runner. Dozens of law review articles have made this mistake, but thankfully at least one law and baseball scholar did not repeat this claptrap. See Michael J. Yelnosky, "If You Write, (S)He Will Come: Judicial Opinions, Metaphors, Baseball, and the Sex Stuff," Connecticut Law Review 28, no. 3 (1996): n. 125.

${ }_{58}^{57}$ As quoted in Weber, As They See 'Em, 115.

${ }^{58}$ Kevin Kaduk, "Erick Aybar's Footwork (or Lack Thereof) Creates a Giant Gray Area," Yahoo Sports, October 18, 2009, http://sports.yahoo.com/mlb/blog/big_league_stew/post/Erick-Aybar-s-footwork-or-lack-thereofcreates?urn=mlb, 196580 .

59 "Bay struck out to end the inning. Nice of Tim McClelland to let us know half an hour later." "Mets-Marlins: New York Takes Game Three in Puerto Rico, Wins 6-5," Bleacher Report, July 1, 2010, http://bleacherreport.com/articles/414012-mets-take-game-3-in-puerto-rico-win-6-5.
} 
write an opinion that contains the only possible correct answer to a legal problem. In order to arrive at that answer, the judge must consider all of the facts, rules, and principles involved in a controversy; weigh them appropriately; and apply them to political morality in a constructive interpretation. Such a task can often be difficult, so Dworkin introduces "an imaginary judge of superhuman intellectual power and patience," whom he calls Hercules. ${ }^{60}$ It may be easy to apply rules in the heat of battle, while it is more difficult to weight principles in that same fast-paced environment, but those principles exist nonetheless.

Dworkin, likely, would not support the tests umpires use to determine the application of the infield fly rule or the balk. As the foregoing examples have demonstrated, often times these tests reveal false positives: they penalize conduct that was not either intended to undermine the fairness of the game or what no real possibility of doing so. Such a system of adjudication becomes mechanical to the point that umpires lose sight of the underlying reasons why both those rules were adopted in the first place, which is important to a Dworkinian legal system.

\section{Post-Game Wrap-up}

When positivism offers one choice to umpires and interpretivism offers a different one, why do umpires choose one path over the other? Speaking from my own experience, the answer is a shared set of baseball norms derived from experience. When a positivist approach offers an efficient and fair solution to a baseball controversy, umpires tend to employ it. When the higher principles of the game demand that umpires look beyond individual rules, they often utilize an interpretivist approach. This might seems like a malleable theory of umpiring behavior, but layers and managers usually know what type of jurisprudence to expect from umpires because

\footnotetext{
${ }^{60}$ Dworkin, Law's Empire, 239. The judicial Hercules should not be confused with the God of umpiring. See "Doug Harvey," Baseball Reference, March 1, 2013, http://www.baseball-reference.com/bullpen/Doug_Harvey.
} 
they, too, understand those norms. The unwritten code of baseball ${ }^{61}$ is almost as important as the rulebook, and it regulates how players relate to each other and how umpires deal with players as well.

This pragmatic approach to choosing an umpiring jurisprudence resonates with most fans of the game because they understand how some circumstances in baseball are different from others. Most fans agreed that calling George Brett out for his pine tar made no sense, but they also expect umpires to maintain a consistent strike zone for both teams and across all nine innings. From a broader perspective, most Americans are not dogmatic about either jurisprudence being applied to real legal controversies. We expect two criminals to receive similar sentences for committing similar crimes, while no one would favor giving a speeding ticket to a husband rushing his wife to the hospital when she has gone into labor.

In short, human behavior is too complicated to fit neatly into a single system in every instance. Debating whether or not Sam Holbrook made the right call in the NL Wild Card game is, in part, why baseball is the national pastime. Likewise, debating how to interpret a 225 year old Constitution in changing circumstances is, in part, why that document remains at the heart of American life. As Professor Gerald Early put it: "When they study our civilization two thousand years from now, there will only be three things that Americans will be known for: the

\footnotetext{
${ }^{61}$ Jason Turbow and Michael Duca, The Baseball Codes: Beanballs, Sign Stealing, and Bench-Clearing Brawls: The Unwritten Rules of America's Pastime (Anchor, 2011). Tim Kurkjian of ESPN has told the greatest example of justice achieved under the Baseball Code: "Many, many years ago, Wayne Gross hit a home run off Ed Farmer and took his time running around the bases. Farmer was furious and wanted to retaliate, but being a reliever who often worked only one inning per game, he didn't face Gross again for three years. And when he did, it was spring training, and they were teammates. The first pitch in batting practice, Farmer hit Gross right in the middle of the back with a fastball at $90 \mathrm{mph}$.

"What was that for?" Gross screamed at Farmer.

"That was for three years ago!" Farmer yelled at Gross.

"OK," Gross said.

And then it was over." Tim Kurkjian, "Retaliation Is a Requirement in Baseball," ESPN.com, April 15, 2013, http://espn.go.com/mlb/story/_/id/9167314/retaliation-requirement-major-league-baseball.
} 
Constitution, baseball, and jazz music. They're the three most beautiful things Americans have ever created."

${ }^{62}$ Quoted in David Hajdu, "Not Quite All That Jazz," The New York Review of Books, February 8, 2001, http://www.nybooks.com/articles/archives/2001/feb/08/not-quite-all-that-jazz/. 